\title{
Research Article \\ Effects of the Absorption Behaviour of ZnO Nanoparticles on Cytotoxicity Measurements
}

\author{
Nigar Najim, ${ }^{1,2}$ Roshidah Rusdi, ${ }^{3}$ Ahmad Sazali Hamzah, ${ }^{4}$ Zurina Shaameri, ${ }^{4}$ \\ Mazatulikhma Mat Zain, ${ }^{1}$ and Norlida Kamarulzaman ${ }^{3}$ \\ ${ }^{1}$ Tissue Culture Research Laboratory, Centre of Synthesis and Chemical Biology, Institute of Science, \\ Universiti Teknologi MARA, 40450 Shah Alam, Malaysia \\ ${ }^{2}$ Department of Pharmacognosy and Pharmaceutical Chemistry, School of Pharmacy, Faculty of Medicine, \\ University of Sulaimani, Iraq \\ ${ }^{3}$ Nanomaterials Research Laboratory, Centre for Nanomaterials Research, Institute of Science, \\ Universiti Teknologi MARA, 40450 Shah Alam, Malaysia \\ ${ }^{4}$ Centre of Synthesis and Chemical Biology, Institute of Science, Universiti Teknologi MARA, 40450 Shah Alam, Malaysia \\ Correspondence should be addressed to Norlida Kamarulzaman; norlyk@salam.uitm.edu.my
}

Received 23 September 2013; Revised 24 December 2013; Accepted 7 January 2014; Published 25 February 2014

Academic Editor: Xuedong Bai

Copyright (C) 2014 Nigar Najim et al. This is an open access article distributed under the Creative Commons Attribution License, which permits unrestricted use, distribution, and reproduction in any medium, provided the original work is properly cited.

\begin{abstract}
$\mathrm{ZnO}$ absorbs certain wavelengths of light and this behavior is more pronounced for nanoparticles of $\mathrm{ZnO}$. As many toxicity measurements rely on measuring light transmission in cell lines, it is essential to determine how far this light absorption influences experimental toxicity measurements. The main objective was to study the $\mathrm{ZnO}$ absorption and how this influenced the cytotoxicity measurements. The cytotoxicity of differently sized $\mathrm{ZnO}$ nanoparticles in normal and cancer cell lines derived from lung tissue (Hs888Lu), neuron-phenotypic cells (SH-SY5Y), neuroblastoma (SH-SY5Y), human histiocytic lymphoma (U937), and lung cancer (A549) was investigated. Our results demonstrate that the presence of $\mathrm{ZnO}$ affected the cytotoxicity measurements due to the absorption characteristic of $\mathrm{ZnO}$ nanoparticles. The data revealed that the $\mathrm{ZnO}$ nanoparticles with an average particle size of around $85.7 \mathrm{~nm}$ and $190 \mathrm{~nm}$ showed cytotoxicity towards U937, SH-SY5Y, differentiated SH-SY5Y, and Hs888Lu cell lines. No effect on the A549 cells was observed. It was also found that the cytotoxicity of $\mathrm{ZnO}$ was particle size, concentration, and time dependent. These studies are the first to quantify the influence of $\mathrm{ZnO}$ nanoparticles on cytotoxicity assays. Corrections for absorption effects were carried out which gave an accurate estimation of the concentrations that produce the cytotoxic effects.
\end{abstract}

\section{Introduction}

The industrial use of nanoparticles in a wide variety of applications has been rapidly expanding in the last decade [1]. Such applications include the use of zinc, titanium, magnesium, and other metallic oxide nanoparticles, thereby increasing the occupational and other environmental exposure of these nanoparticles to humans and other species [2].

Zinc oxide $(\mathrm{ZnO})$ has properties such as wide band gap $(3.37 \mathrm{eV})$, high exciton binding energy $(60 \mathrm{meV})$, and a variety of morphologies [3]. $\mathrm{ZnO}$ nanoparticles have unique properties including small size and correspondingly large-specific surface area to volume ratio. $\mathrm{ZnO}$ has been increasingly employed in a variety of industrial applications including production of wave filters, UV detectors, catalysts, paint, transparent conductive film, cosmetics, gas sensor and catalytic processes, solar cells and microelectronics [4-12], personal care products (toothpaste, beauty products, and sunscreens [13]), and textiles [14]. Increased applications in industry will increase chances of exposure of the nanoparticles to humans. Thus, zinc oxide nanoparticles are the subject of much research because of their high probability exposure to human and environment [1].

Nanoparticles exhibit unique physiochemical properties and can have many unknown biological effects. Effects of $\mathrm{ZnO}$ nanoparticles on bacteria [12, 15], algae [16, 17], crustaceans [15], nematodes [18], and yeast Saccharomyces cerevisiae [19] have been studied. Many research groups 
studied the effects of $\mathrm{ZnO}$ nanoparticles on eukaryotic cell lines such as human neuron cells [2,20], epidermal [21], lung cancer [22, 23], intestinal [24], lymphocytes [25], and normal cells $[22,25,26]$. Lockman et al. (2004) reported that nanoparticles can alter blood-brain barrier integrity and permeability [27]. Later Tiwari and Amiji (2006) demonstrated nanocarrier-based central nervous system (CNS) delivery system for enhancing drug transport into the CNS [28]. Another group investigated zinc oxide nanoparticle penetration in human skin in vitro and in vivo [29]. However, none of these studies took into account the light absorption effects of the nanopowders themselves and the consequences on toxicology measurements.

In this study, we evaluated the possible contribution of $\mathrm{ZnO}$ nanoparticles absorption in the readings of cytotoxicity measurements. We also demonstrated cytotoxicity of two different sizes of spherically shaped $\mathrm{ZnO}$ nanoparticles in normal and cancer cell lines derived from different histological origin. Finally, we evaluated that the cytotoxicity of $\mathrm{ZnO}$ was particle size, concentration, and time dependent.

\section{Materials and Methods}

2.1. $\mathrm{ZnO}$ Nanoparticles. The $\mathrm{ZnO}$ nanoparticles were synthesized using a method detailed elsewhere [30]. Two groups of $\mathrm{ZnO}$ nanoparticles with the average particle size of around $85.7 \mathrm{~nm}$ and $190 \mathrm{~nm}$ named $\mathrm{Z} 1$ and $\mathrm{Z} 2$ were used, respectively. The $\mathrm{ZnO}$ nanoparticle size of one sample is twice that of the other sample. The absorption of the $\mathrm{ZnO}$ nanoparticles was measured using Perkin Elmer Lambda 750 UV-Vis-NIR spectrophotometer with a range of about 330 to $700 \mathrm{~nm}$. The reflectance mode was used for the measurements.

The micrographs from the field emission transmission electron microscope (FETEM) are obtained from the JEOL JEM2100F. The microstructures can clearly be seen from the phase contrast image.

The stock solutions of $\mathrm{ZnO}$ nanoparticles ( $\mathrm{Z} 1$ and $\mathrm{Z2}$ ) were prepared in phosphate buffer saline (PBS, $0.01 \mathrm{M}$, Sigma, USA), with $100 \mathrm{mM}$ stock concentration, sonicated for 30 minutes, and stored at $4^{\circ} \mathrm{C}$. The nanoparticles stock concentrations were vigorously vortexed and then diluted with complete medium prior each experiment, resulting in a series of final concentrations ranging from $50 \mu \mathrm{M}$ to $10 \mathrm{mM}$. Dose response effects of $\mathrm{ZnO}$ nanoparticles to cancer and normal cell lines were evaluated at two different exposure times, 24 and $96 \mathrm{~h}$.

2.2. Cell Lines and Culture Conditions. Human medulloblastoma SH-SY5Y cell line was a gift from Dr. Carol Sanfeliu (Department of Pharmacology and Toxicology, Institute of Biological Research, Barcelona, Spain). Lymphoma U937 and lung cancer A549 cell lines were a gift from Dr. Mohamed Saifulaman (Faculty of Applied Sciences, UiTM, Malaysia). Normal lung Hs888Lu cell lines were purchased from American Type Culture Collection (ATCC, The Global Bioresource Centre, Manassas, USA).

The SH-SY5Y, U937, and A549 cells were cultured in Dulbecco's Modified Eagle's Medium (DMEM, Sigma, USA) with high glucose content, $1 \%$ nonessential amino acids (100×) (PAA Laboratory GmbH, Austria), 1\% L-glutamine $(200 \mathrm{mM})$ (Sigma, USA), and $1 \%$ gentamicin $(10 \mathrm{mg} / \mathrm{mL})$ (PAA Laboratory $\mathrm{GmbH}$, Austria) and supplemented with $10 \%$ fetal bovine serum (FBS, PAA Laboratory $\mathrm{GmbH}$, Austria). For treatment experiments neuroblastoma (SH-SY5Y) cells were adapted to grow in 1:1 of Minimum Essential Medium Eagle: nutrient mixture F12-Ham (EMEM: HamsF12, Sigma, USA) with $1 \%$ nonessential amino acids, $1 \%$ L-glutamine, and $1 \%$ gentamicin and supplemented with $10 \%$ FBS. Hs888Lu was adapted to grow in DMEM with high glucose content, $1 \%$ nonessential amino acids, $2 \%$ L-glutamine $(200 \mathrm{mM}), 1 \%$ penicillin/streptomycin $(100 \times)$ (PAA Laboratories $\mathrm{GmbH}$, Austria), and $1 \%$ sodium pyruvate $(1 \mathrm{mM})$ (Sigma-Aldrich, USA) and supplemented with $10 \%$ FBS. All cell lines were maintained in an incubator (Contherm Scientific Ltd, New Zealand) at $37^{\circ} \mathrm{C}$ in a $5 \%$ $\mathrm{CO}_{2}$ atmosphere with $95 \%$ humidity. Culture conditions were optimized for each cell line.

2.3. Assay for Cytotoxic Activity. Cells $\left(1 \times 10^{5}\right.$ cells $\left./ \mathrm{mL}\right)$ were seeded in 96-well plates and left to grow overnight in humidified atmosphere containing $5 \% \mathrm{CO}_{2}$ at $37^{\circ} \mathrm{C}$. On the following day, cells were treated with serial dilution of $\mathrm{ZnO}$ concentrations ranging from $50 \mu \mathrm{M}$ to $10 \mathrm{mM}$. After $24 \mathrm{~h}$ and $96 \mathrm{~h}$ cell viability was measured by CellTiter $96 \mathrm{AQ}_{\text {ueous }}$ Assay which uses the novel tetrazolium compound (3-(4,5-dimethylthiazol2yl)-5-(3-carboxymethoxyphenyl)-2-(4-sulfophenyl)2H-tetrazolium, inner salt) (MTS, Promega, USA) using Glomax multidetection system (Promaga, USA) and read at $490 \mathrm{~nm}$ [31]. Results were representative of at least three independent experiments and were expressed as percentage of the value observed with a control which contained no $\mathrm{ZnO}$.

2.4. Assay for Neurotoxicity. Retinoic acid (RA, Sigma, USA) will induce the differentiation of the neuroblastoma cells (SH-SY5Y) to behave like neuron-phenotypic cells [32, 33]. Approximately, $1 \times 10^{4}$ cells $/ \mathrm{mL}$ were seeded in 96-well plates. After $24 \mathrm{~h}, \mathrm{RA}$ was added at a final concentration of $10 \mu \mathrm{M}$ in complete EMEM-F12 media. The medium in the plate was changed at day 3 with fresh RA and cultures were ready to be tested on day $6 . \mathrm{ZnO}$ nanoparticles (both groups) were tested for their neurotoxicity effect. The nanoparticles serial dilutions in EMEM-F12 were made fresh prior to each test. For neurotoxicity, the differentiated SH-SY5Y cells in each well were tested with final concentrations of $\mathrm{ZnO}$ nanoparticles ranging from $50 \mu \mathrm{M}$ to $10 \mathrm{mM}$. The wells were agitated lightly and incubated for $24 \mathrm{~h}$ or $96 \mathrm{~h}$. Following treatments, cell viability was assessed with Cell Titer 96* Aqueous Non-Radioactive Cell Proliferation Assay (MTS, Promega, USA). The MTS assay is a colorimetric assay based on the reduction of 3-(4,5-dimethylthiazol-2-yl)-5-(3 carboxymethoxyphenyl)2(4 sulfophenyl)-2H-tetrazolium (MTS) by dehydrogenase enzymes found in metabolically active cells. The amount of colour formazan product is proportional to the number of viable cells. Briefly, $20 \mu \mathrm{L}$ MTS solution was added to each well and incubated in humidified incubator at $37^{\circ} \mathrm{C}$ in $5 \%$ 
$\mathrm{CO}_{2}$ for 2-4 h in the dark. The quantity of formazan product present was determined by measuring the absorbance at $490 \mathrm{~nm}$ with a microtiter plate reader (GloMax Integrated Systems by Promega, USA). Values were expressed as the percentage of optical density of control cells (nontreated).

\subsection{Interference of $\mathrm{ZnO}$ Nanoparticles with the Cell Viability} Measurements. $\mathrm{ZnO}$ absorption and its influence on the reading of the cytotoxicity measurements were studied. A nanoparticles-free assay was developed to investigate the direct interference of $\mathrm{ZnO}$ nanoparticles ( $\mathrm{Z1}$ or $\mathrm{Z} 2$ ) with cell viability assay. Cells $\left(1 \times 10^{5}\right.$ cells $\left./ \mathrm{mL}\right)$ were seeded in 96 -well plates and left to grow overnight. The following day, cells were treated with serial dilution of $\mathrm{ZnO}$ concentrations ranging from $50 \mu \mathrm{M}$ to $10 \mathrm{mM}$. After 24 or $96 \mathrm{~h}$ the supernatant containing excess of $\mathrm{ZnO}$ nanoparticles that did not attach to the cells or culture plates was disposed and gently the cells were washed with PBS twice. $100 \mu \mathrm{L}$ of fresh media was then added to each well followed by $20 \mu \mathrm{L}$ MTS reagent. Thereafter, the absorbance for cell with $\mathrm{ZnO}$ and cell-free $\mathrm{ZnO}$ system was determined by reading at $490 \mathrm{~nm}$ wavelength of the MTS assay. Nontreated cultures were used as controls.

\subsection{Interference of MTS Reagents with the Cell Viability} Measurements. Cells $\left(1 \times 10^{5}\right.$ cells $\left./ \mathrm{mL}\right)$ were seeded in $96-$ well plates and left to grow overnight. On the following day, cells were treated with serial dilution of $\mathrm{ZnO}$ concentrations ranging from $50 \mu \mathrm{M}$ to $10 \mathrm{mM}$. After 24 or $96 \mathrm{~h}$ the interference of MTS reagent with the cell viability assay was assessed by measuring the absorbance of treated culture in the absence of MTS reagent. The absorbance with and without MTS was measured at $490 \mathrm{~nm}$.

2.7. Cell Morphology. Interference of $\mathrm{ZnO}$ nanoparticles was also evident by morphological changes that appeared in cell lines. Prior to strong changes in metabolism or proliferation, cells often change their shape in response to toxic reagents. The changes in the morphology of cell lines treated with various $\mathrm{ZnO}$ nanoparticles concentrations for 24 and 96 hours were compared to that of corresponding cell-free $\mathrm{ZnO}$ and untreated cells, by confocal microscopy. Bright field images of cells were acquired with $40 \times$ objective using a Leica confocal microscope (Leica DMI 4000B, Wetzlar, Germany) equipped with a digital camera.

2.8. Statistical Analysis. GraphPad PRISM version 5.0 program was used to create the graphs. All determinations were performed at least in triplicate. Means and standard deviations were determined. All comparisons were made using two-tailed Student's $t$-test, $\left({ }^{*} P<0.05 ;{ }^{*} P<0.01\right.$; $\left.{ }^{* * *} P<0.001\right)$ using GraphPad PRISM version 5.0.

\section{Results and Discussion}

3.1. $\mathrm{ZnO}$ Characterization. The $\mathrm{ZnO}$ nanoparticles used are phase pure as shown in the indexed X-Ray diffraction (XRD) pattern in Figure 1. The $\mathrm{ZnO}$ belongs to the hexagonal crystal structure with no impurity peaks present. The morphology

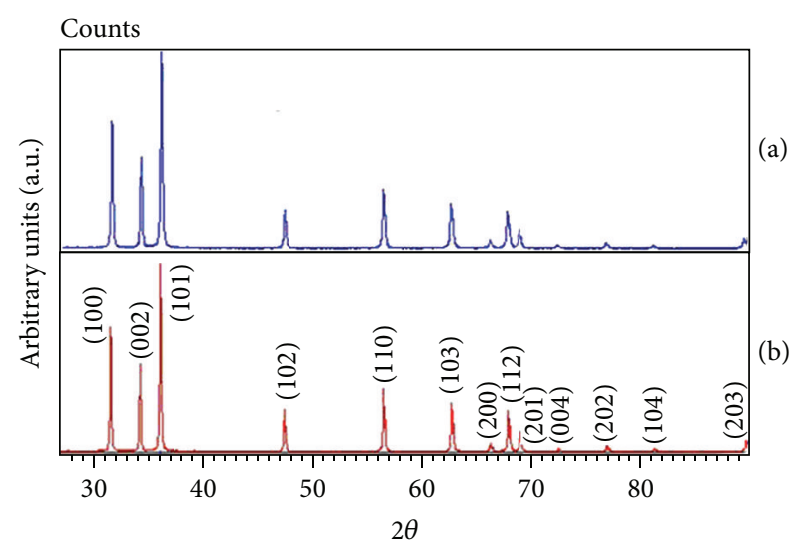

Figure 1: X-Ray diffraction patterns of $\mathrm{ZnO}$ samples. (a) $\mathrm{ZnO}$ annealed at $700^{\circ} \mathrm{C}$ for $30 \mathrm{~min}$ and (b) $\mathrm{ZnO}$ annealed at $700^{\circ} \mathrm{C}$ for $3 \mathrm{~h}$.

of the $\mathrm{ZnO}$ samples is spherical in shape as can be seen in the scanning electron microscopy (SEM) results in Figure 2. From the micrographs, it is obvious that the particle size of the $\mathrm{ZnO}$ has an average size of $85.7 \mathrm{~nm}$ (sample $\mathrm{Z1}$ ) and $190 \mathrm{~nm}$ (sample Z2).

The microstructure of the nano- $\mathrm{ZnO}$ can be clearly seen from the TEM images showing spherical geometries in Figure 3. The size is as estimated earlier using SEM. This is because SEM can give a wider field of view enabling measurements of size on more number of particles giving a statistically better accuracy for average size.

3.2. $U V$-Vis of $\mathrm{ZnO}$. The reflectance measurement of $\mathrm{ZnO}$ is shown in Figure 4. It can be seen that the absorption edge of the materials is about $390 \mathrm{~nm}$. The measurement for the toxicity studies is at $490 \mathrm{~nm}$. Even though the absorption edge is at $390 \mathrm{~nm}$, there is still about $1.3 \%$ of absorption of light at $490 \mathrm{~nm}$. This absorption at $490 \mathrm{~nm}$ will affect the toxicity measurements made in the experiments, especially when the density of $\mathrm{ZnO}$ in the samples is high.

3.3. Studies of the Effects and Interference of Nanoparticles with Cytotoxicity Data. Absorbance reading at $490 \mathrm{~nm}$ shows an increase in cell viability compared to the control (nontreated) after treatment with $\mathrm{ZnO}$ nanoparticles above $1 \mathrm{mM}$ concentration (Figures 8-10), which is not logical. Thus, questions arise as to the effect of the $\mathrm{ZnO}$ nanoparticles themselves and/or MTS reagent on the measurements for the absorbance at $490 \mathrm{~nm}$. Therefore, a nanoparticles-free assay was developed to investigate the direct interference of $\mathrm{ZnO}$ nanoparticles with absorbance measurements and then with cell viability assay. The results show a significant decrease ( $P$ 's $<0.01)$ in the relative percentage absorbance after removing $\mathrm{ZnO}$ nanoparticles from the culture system compared with the system in the presence of $\mathrm{ZnO}$ nanoparticles at the concentrations of more than $1 \mathrm{mM}$ (Figure 5). The cells treated with $\mathrm{ZnO}$ nanoparticles concentrations equal or less than $1 \mathrm{mM}$ do not show significant change under the $\mathrm{ZnO}$ 


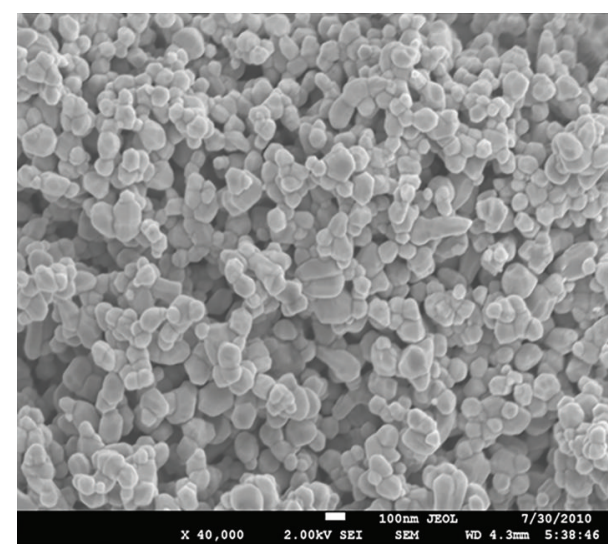

(a)

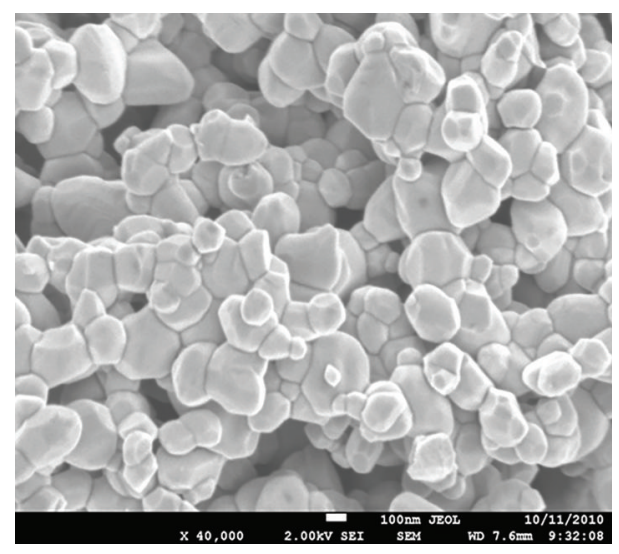

(b)

Figure 2: SEM micrographs (a) of $\mathrm{ZnO}$ annealed at $700^{\circ} \mathrm{C}$ for $30 \mathrm{~min}$ and (b) $\mathrm{ZnO}$ annealed at $700^{\circ} \mathrm{C}$ for $3 \mathrm{~h}$.

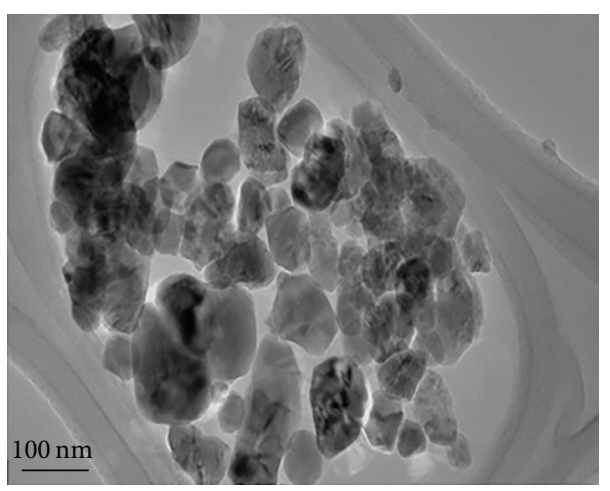

(a)

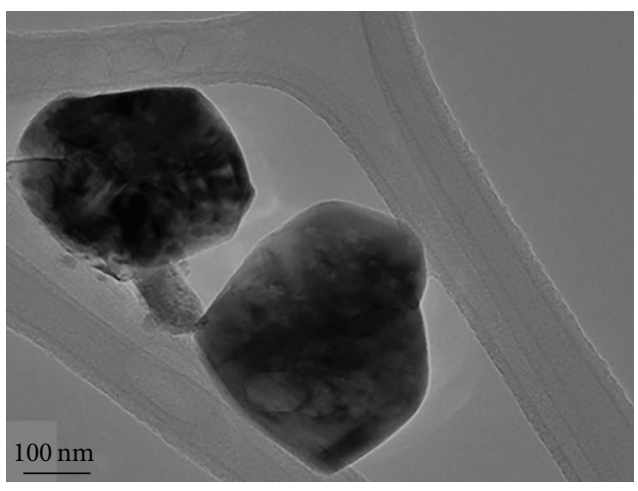

(b)

Figure 3: TEM images of $\mathrm{ZnO}$ annealed at $700^{\circ} \mathrm{C}$ for (a) 30 minutes and for (b) $3 \mathrm{~h}$.

and $\mathrm{ZnO}$-free conditions. This implies that absorbance of the $490 \mathrm{~nm}$ wavelength of light is only significant for higher concentrations of $\mathrm{ZnO}$.

Previous researches lead us to explore the applicability and limits of MTS assay for the evaluation of cytotoxicity data. Previously, several studies highlighted the interference of carbon nanotubes and other nanomaterials with cytotoxicity dyes, including 2-(4,5-dimethyl-2-thiazolyl)3,5-diphenyl-2H-tetrazolium bromide (MTT), neutral red, 2-(4-iodophenyl)-3-(4-nitrophenyl)-5-(2,4-disulfophenyl)2H-tetrazolium (WST-1), MTS, and coomassie blue and alamar blue [34-40]. Only one publication by Ostrovesky et al. (2009) addressed the cytotoxicity effects of high concentration ranges of $\mathrm{ZnO}$ nanoparticles between 1.5$10 \mathrm{mM}$ in glioma cell lines and normal human astrocytes [41], but the interference of $\mathrm{ZnO}$ nanoparticles with the absorbance measurement at $490 \mathrm{~nm}$ was not investigated or reported; it should be noted that they examined cytotoxicity of $\mathrm{ZnO}$ nanoparticles using lactate dehydrogenase (LDH) release. Our findings showed an interference of $\mathrm{ZnO}$ nanoparticles with absorbance readings at $490 \mathrm{~nm}$ at concentrations above $1 \mathrm{mM}$ (Figure 5) and these results are novel.
3.4. Studies of the Effects and Interference of MTS Reagent with Cytotoxicity Data. The interference of MTS reagent with the cell viability assay was also assessed by measuring the absorbance of treated cell lines in the absence of MTS reagent. Our novel findings with regard to MTS interference demonstrated the dramatic increase $(P$ 's $<0.01)$ in absorbance reading at $490 \mathrm{~nm}$ in the absence of MTS reagents at concentrations above $1 \mathrm{mM}$ compared to the control cells (no $\mathrm{ZnO}$ ). No increase in absorbance measurements was observed below $1 \mathrm{mM} \mathrm{ZnO}$ nanoparticles (Figure 6).

This observation is suggesting that MTS reagent is not involved and the nanoparticles themselves may be interfering in the increase in absorbance reading. The results demonstrated that after the elimination of $\mathrm{ZnO}$ nanoparticles from the culture condition, the percentages of relative absorbance significantly decrease at the concentrations above $1 \mathrm{mM}$. This has not been reported previously.

3.5. Cell Morphology. Interference of $\mathrm{ZnO}$ nanoparticles was also evident by morphological changes that appeared in cell lines. The current study therefore routinely included bright field microscopic analysis of cell cultures. After $96 \mathrm{~h}$ 


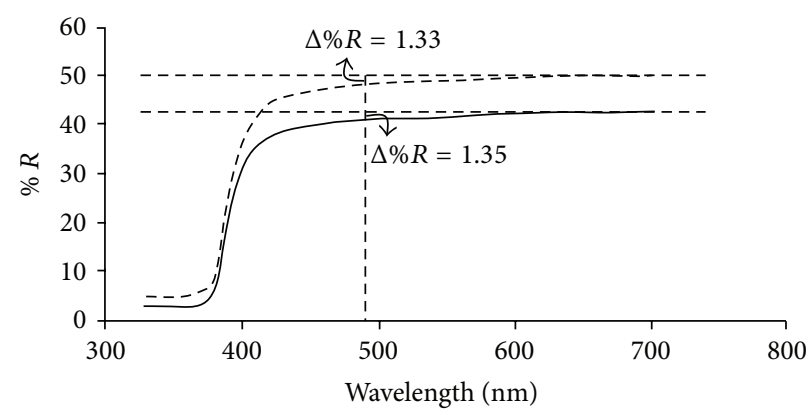

(a)

(b)

Figure 4: UV-Vis results of (a) $\mathrm{ZnO}$ annealed at $700^{\circ} \mathrm{C}$ for $3 \mathrm{~h}$ and (b) $\mathrm{ZnO}$ annealed at $700^{\circ} \mathrm{C}$ for $30 \mathrm{~min}$.

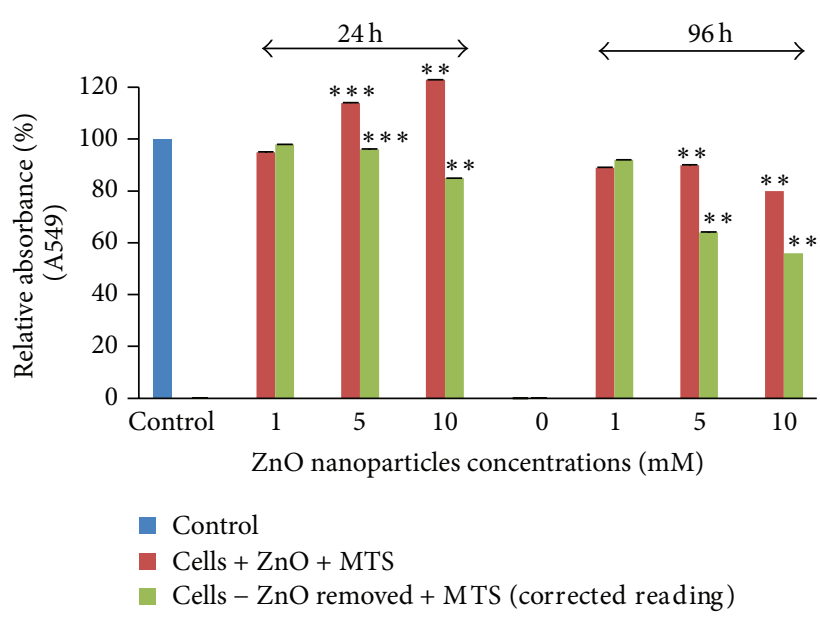

(a)

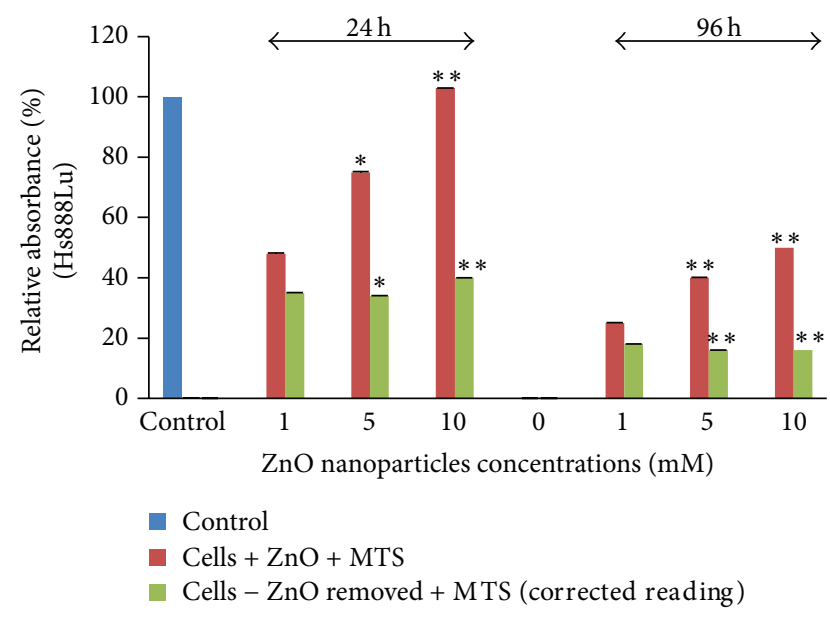

(b)

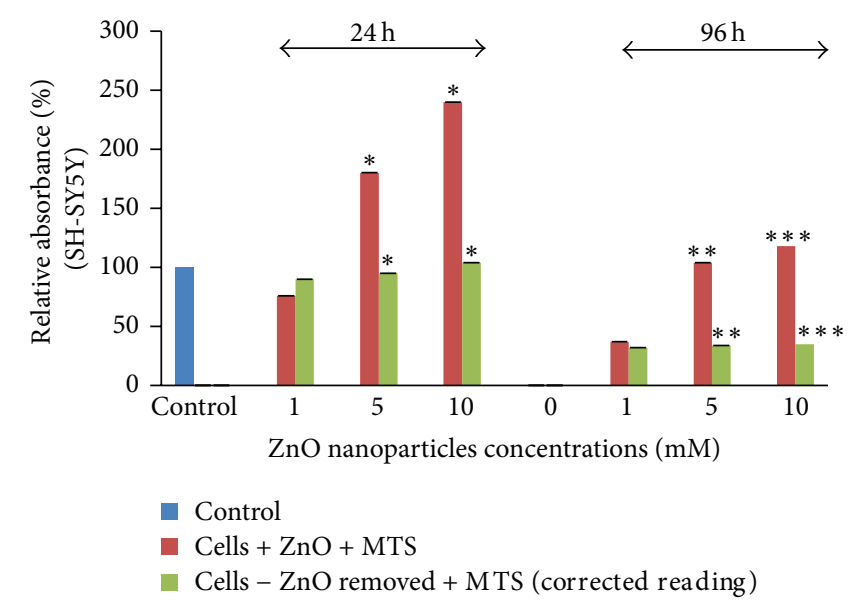

(c)

FIGURE 5: The interference of $\mathrm{ZnO}$ nanoparticles $(85.7 \mathrm{~nm}$ ) in absorbance reading in (a) lung cancer, (b) normal lung, and (c) neuroblastoma cells. Control represents untreated cell lines. Black bars represent cell lines treated with Z1 followed by MTS addition. Gray bars represent cell lines treated with $\mathrm{Z} 1$ followed by disposing $\mathrm{ZnO}$ and addition of MTS (corrected reading). Values are means $\pm \mathrm{SD}(n=3)$ and all comparisons were made using two-tailed Student's $t$-test $\left({ }^{*} P<0.05 ;{ }^{* *} P<0.01 ;{ }^{* * *} P<0.001\right)$. 


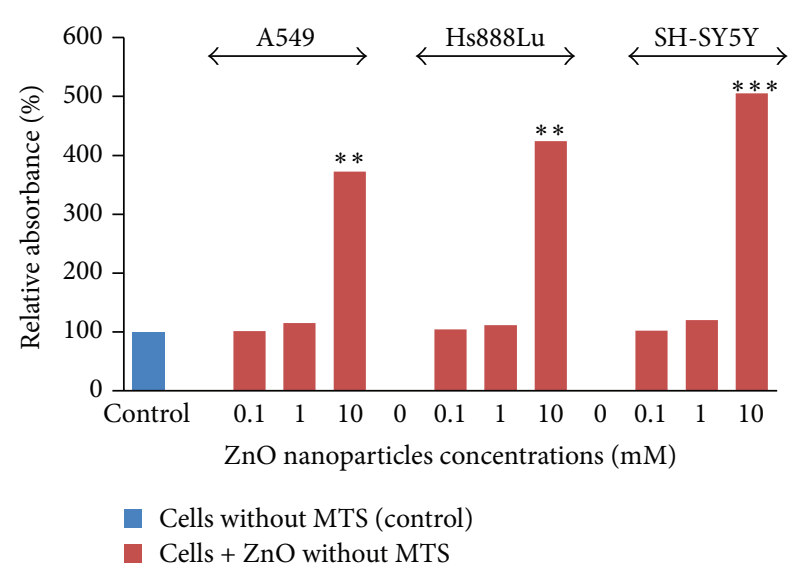

FIGURE 6: The absorbance measurements without MTS reagents in different cell lines. Control represents untreated cell lines. Cells were treated with $\mathrm{Z} 1$ for $24 \mathrm{~h}$. Black bars represent measurements in the absence of MTS. Values are means $\pm \operatorname{SD}(n=3)$ and all comparisons were made using two-tailed Student's $t$-test $\left({ }^{*} P<0.05\right.$; ${ }^{* *} P<0.01$; $\left.{ }^{* * *} P<0.001\right)$.

incubation with $\mathrm{Z} 1$ nanoparticles at $1 \mathrm{mM}$ concentration, SH-SY5Y cells have undergone morphological changes into spherical shape, gained in volume, and formed clusters in media after detachment from cell culture plate (Figure 7(c)). Cellular shrinkage and detachment from the surface of the plate as well as increase in cell death at doses $1 \mathrm{mM}$ and $5 \mathrm{mM}$ were also observed in normal lung cells and neuron-like cell (not shown). In contrast, lung cancer (A549) cell lines treated with $1 \mathrm{mM}$ of $\mathrm{ZnO}$ nanoparticles (Z1) and incubated for $96 \mathrm{~h}$ exhibited no visible morphological changes (Figure 7(d)).

The numbers of dead cells increase with increasing nanoparticles concentration to $5 \mathrm{mM}$ in both SH-SY5Y and A549 cells (Figures 7(e) and 7(f)). While a significant increase in absorbance reading at wavelength of $490 \mathrm{~nm}$ was observed at selected concentration (Figures 8(a) and 9(a)).

Figures 7(g) and 7(h) show the dramatic decrease in the cell number after removing $\mathrm{ZnO}$ nanoparticles and dead cells from the culture system compared with the system in the presence of $\mathrm{ZnO}$ particles at the concentration of $1 \mathrm{mM}$ (Figures 7(c) and 7(d)). The absorbance readings dropped dramatically in the sample where $\mathrm{ZnO}$ nanoparticles have been removed (Figure 5).

In this study we found out that no effects are observed for lung cancer (A549) cell lines exposed to $1 \mathrm{mM}$ of $\mathrm{ZnO}$ nanoparticles, Z1 and Z2 (85.7 nm group and $190 \mathrm{~nm}$ group, resp.), and incubated for 24 or $96 \mathrm{~h}$. In contrast, other studies have described that the cell viability in A549 cell lines was reduced by $75-80 \%$ between 18 and $25 \mu \mathrm{g} / \mathrm{mL}(0.2$ and $0.3 \mathrm{mM}$ ) with $\mathrm{ZnO}$ particles $(70$ and $420 \mathrm{~nm}$ ) between 6

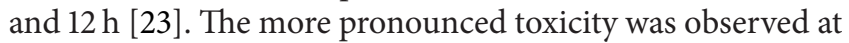
$24 \mathrm{~h}$ [23]. Recently, Kim and coworkers (2010) reported that $\mathrm{ZnO}$ nanoparticles exhibited the cytotoxicity in terms of cell proliferation, cell viability, and membrane integrity in A549 cells [22].

We have shown that $\mathrm{Z} 1$ nanoparticles did induce approximately $50-70 \%$ decrease in cell survival in normal lung cells $\mathrm{Hs} 888 \mathrm{Lu}$ at $1 \mathrm{mM}$ after 24 and $96 \mathrm{~h}$, respectively. $\mathrm{ZnO}$ nanoparticles activity has not been reported previously in such cells by any research group. While, Kim and coworkers (2010) demonstrated the cytotoxic effect of $\mathrm{ZnO}$ nanoparticles in another normal lung cell types (L-132).

3.6. ZnO Cytotoxicity and Neurotoxicity. It is known that different cell lines might exhibit different sensitivities towards zinc oxide nanoparticles [2, 20-28], so the use of more than one cell line is therefore considered necessary in the evaluation of antiproliferative nanoparticles.

Cell lines are treated with $\mathrm{ZnO}$ nanoparticles concentrations ranging from $50 \mu \mathrm{M}$ to $10 \mathrm{mM}$ of average particle sizes $85.7 \mathrm{~nm}(\mathrm{Z} 1)$ and $190 \mathrm{~nm}(\mathrm{Z} 2)$ and incubated for 24 or 96 hours. Our data indicated that exposure to either size of $\mathrm{ZnO}$ nanoparticles samples $\mathrm{Z1}$ and $\mathrm{Z} 2$ induced different toxic effects in the human cell lines tested in this study (Figures 810). $\mathrm{ZnO}$ nanoparticles do not show toxicity in lung cancer cells A549, and they almost maintain $90-100 \%$ cell viability up to $1 \mathrm{mM}$ concentration after exposure to either size of $\mathrm{ZnO}$ nanoparticles for 24 or $96 \mathrm{~h}$ (Figure 8(a)).

We further examined the cytotoxic effect of the $\mathrm{ZnO}$ nanoparticles in normal lung cells Hs888Lu. Cells were exposed to both particle sizes Z1 and Z2 for 24 and $96 \mathrm{~h}$ (Figure 8(b)). It seems that the difference in particle sizes behaves differently in normal lung tissue. Z1 particles induced almost $50 \%$ decrease in cell viability after $24 \mathrm{~h}$ incubation at $0.8 \mathrm{mM}$ and $1 \mathrm{mM}$ concentrations $(P$ 's $<0.01)$. Some cytotoxic effect was already observed after $96 \mathrm{~h}$ treatment with the same particles at $0.2 \mathrm{mM}$ (data not shown), but the most pronounced effect was observed between $0.8 \mathrm{mM}$ to $1 \mathrm{mM}$ concentrations with $70 \%(P$ 's $<0.01)$ viability loss (Figure 8(b)). Z2 particles were less potent in Hs888Lu cell lines, reducing viability by $20 \%$ after $96 \mathrm{~h}$ treatment at $0.8 \mathrm{mM}$ and $1 \mathrm{mM}$ concentrations $(P$ 's $<0.05)$, while no effects were observed after $24 \mathrm{~h}$ incubation.

The cytotoxic responses of different cell lines to $\mathrm{ZnO}$ nanoparticles were found to be different. To assess if $\mathrm{ZnO}$ nanoparticles may exert cytotoxicity on human neuron cells similar to those of cancer and normal lung cells, we also studied the cytotoxicity and neurotoxicity effects of $\mathrm{ZnO}$ nanoparticles on neuroblastoma (SH-SY5Y) and neuron-like cells (differentiated SH-SY5Y). Exposure of SH-SY5Y and differentiated SH-SY5Y cells to ZnO nanoparticles Z2 for $24 \mathrm{~h}$ at $1 \mathrm{mM}$ concentration induces a decrease in cell survival to $60 \%$ and $80 \%$ ( $P$ 's $<0.01)$, respectively (Figure 9 ). The longer incubation for $96 \mathrm{~h}$ significantly decreases the cell survival to less than $50 \%$ in both cell lines at $0.8-1 \mathrm{mM}$ concentrations $(P$ 's $<0.01)$.

It seems that smaller particles average size of $85.7 \mathrm{~nm}$ (Z1) has exhibited more cytotoxic activity in both cell lines, where potent cytotoxic effect had been observed at a low concentration of $0.4 \mathrm{mM}$ with $\mathrm{Z1}$ nanoparticles. Some effects of Z2 were observed at $0.8 \mathrm{mM}$ in both SH-SY5Y ( $P$ 's < $0.01)$ and differentiated SH-SY5Y $(P$ 's $<0.05)$ cell lines after $96 \mathrm{~h}$. Exposure of these cells to $\mathrm{Zl}$ particles for $96 \mathrm{~h}$ at concentrations ranging between $0.4 \mathrm{mM}$ and $1 \mathrm{mM}$ induced a decrease $(P$ 's $<0.01)$ in cell survival to almost $30-40 \%$ (Figure 9). 


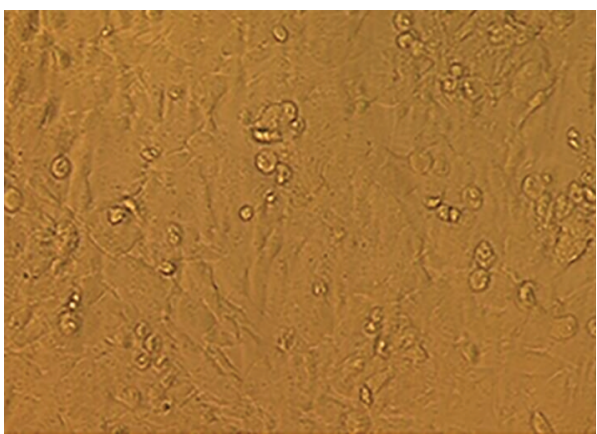

(a) SH-SY5Y-(control)

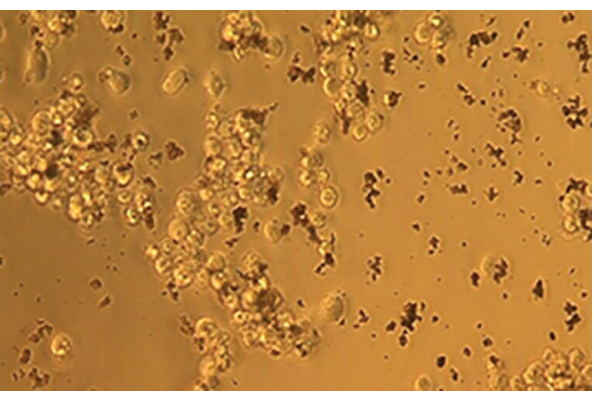

(c) SH-SY5Y-1 mM/96h

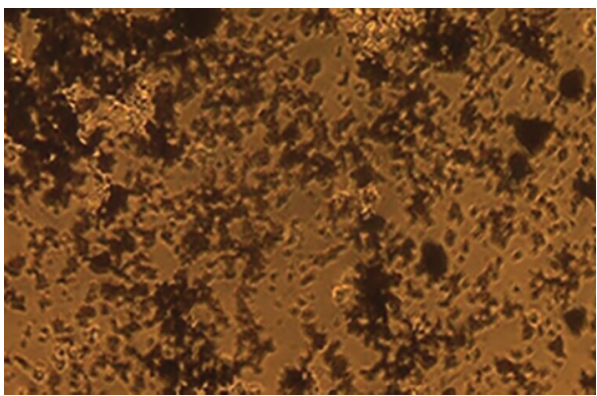

(e) SH-SY5Y- $5 \mathrm{mM} / 96 \mathrm{~h}$

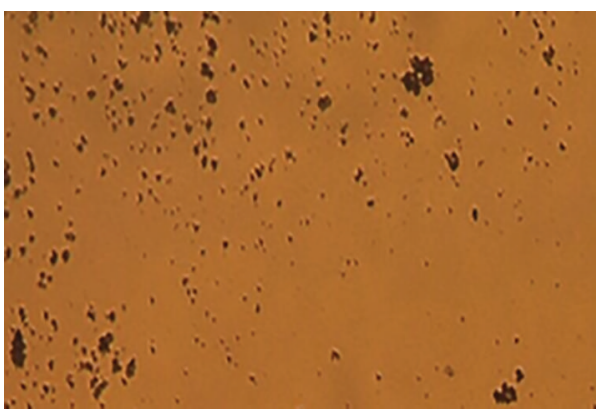

(g) SH-SY5Y-5 mM/96 h (ZnO disposed)

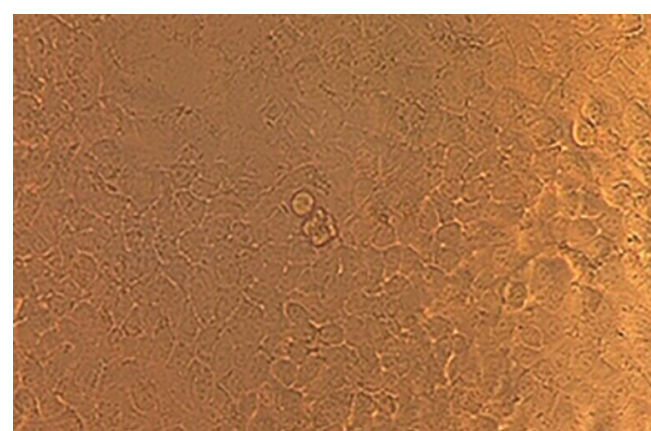

(b) A549- (control)

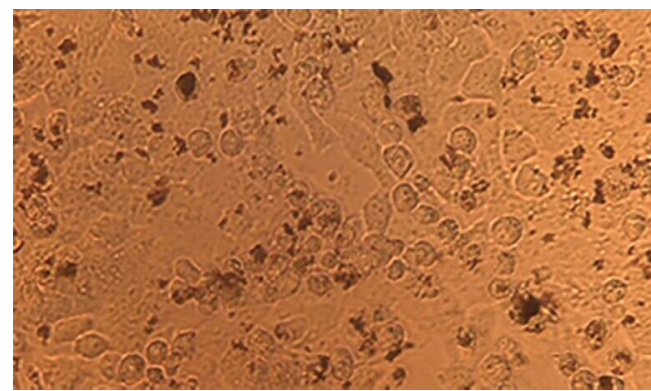

(d) A549-1 mM / 96h

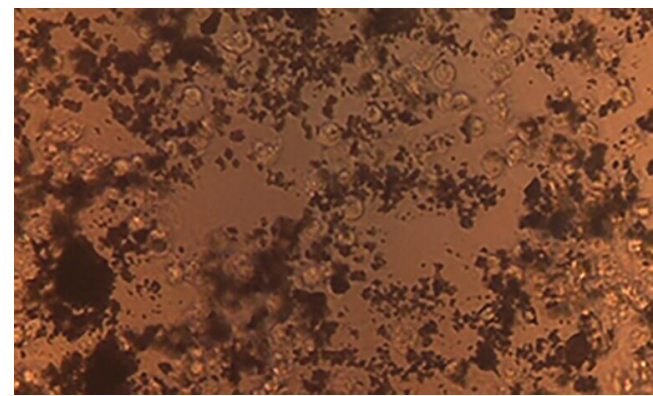

(f) $\mathrm{A} 549-5 \mathrm{mM} / 96 \mathrm{~h}$

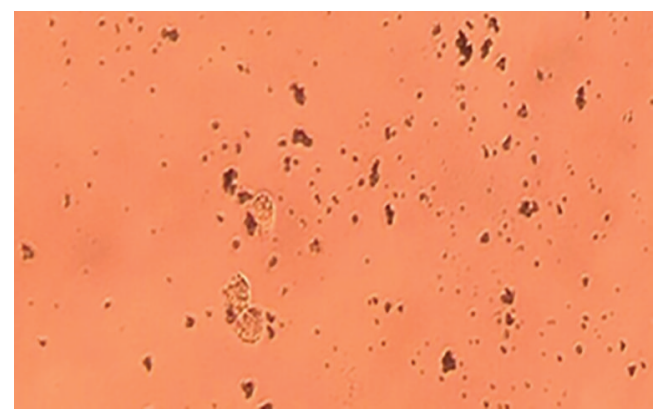

(h) A549-5 mM/96 h ( $\mathrm{ZnO}$ disposed)

Figure 7: Morphological changes of A549 and SH-SY5Y cell lines after $96 \mathrm{~h}$ incubation in Z1 (85.7 nm) nanoparticles: (a) and (b), control cells in regular cell culture (no nanoparticles); (c) and (d), cell lines treated with $1 \mathrm{mM}$ of $\mathrm{Z1}$ nanoparticles; (e) and (f), cell lines treated with $5 \mathrm{mM}$ of $\mathrm{Zl}$; ( $\mathrm{g}$ ) and (h), cell lines treated with $5 \mathrm{mM}$ of $\mathrm{Zl}$ followed by disposing $\mathrm{ZnO}$.

Chen and colleagues reported that $\mathrm{ZnO}$ and iron oxide $\left(\mathrm{Fe}_{2} \mathrm{O}_{3}\right)$ nanoparticles do not induce significant decrease of cell viability in SH-SY5Y cell lines at a concentration range of $0.01-100 \mu \mathrm{M}$ for $48 \mathrm{~h}$ [20]. This is in agreement with our finding for SH-SY5Y and differentiated SH-SY5Y, where no effects were observed after exposure to $\mathrm{ZnO}$ nanoparticles at concentration $100 \mu \mathrm{M}$ for 24 and $96 \mathrm{~h}$ (data not shown). From our literature review no studies were reported on nanoparticles cytotoxicity in neuron-like (differentiated SHSY5Y) cell lines.

Another human cell line from different histological origin, lymphoma (U937), was tested for its sensitivity to 


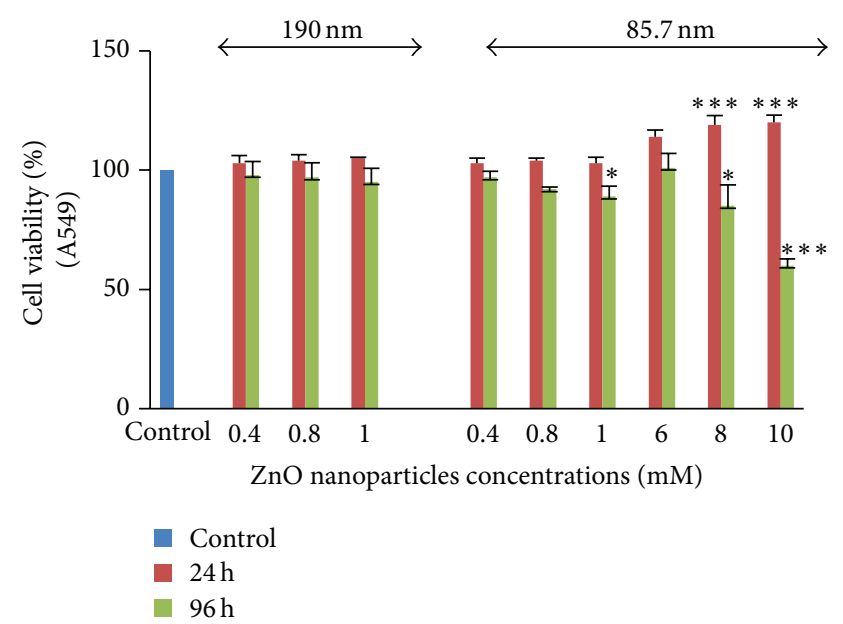

(a)

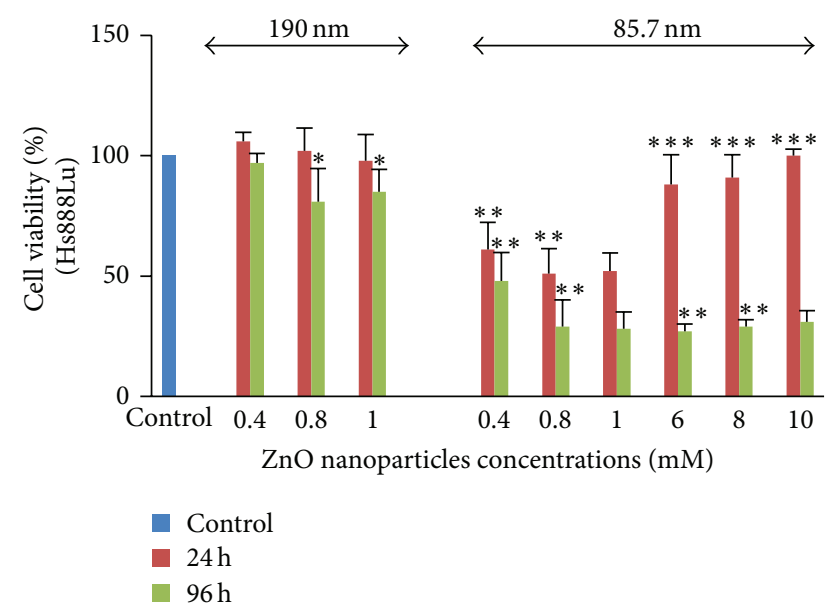

(b)

Figure 8: Cytotoxicity effects of ZnO nanoparticles, Z1 $(85.7 \mathrm{~nm})$ and $\mathrm{Z2}(190 \mathrm{~nm})$, after 24 or $96 \mathrm{~h}$ incubation in (a) lung cancer cell lines (A549) and (b) normal lung (Hs888Lu) cells. Control represents untreated cell lines. Values are means \pm SD $(n=3)$ and all comparisons were made using two-tailed Student's $t$-test $\left({ }^{*} P<0.05 ;{ }^{* *} P<0.01 ;{ }^{* * *} P<0.001\right)$.

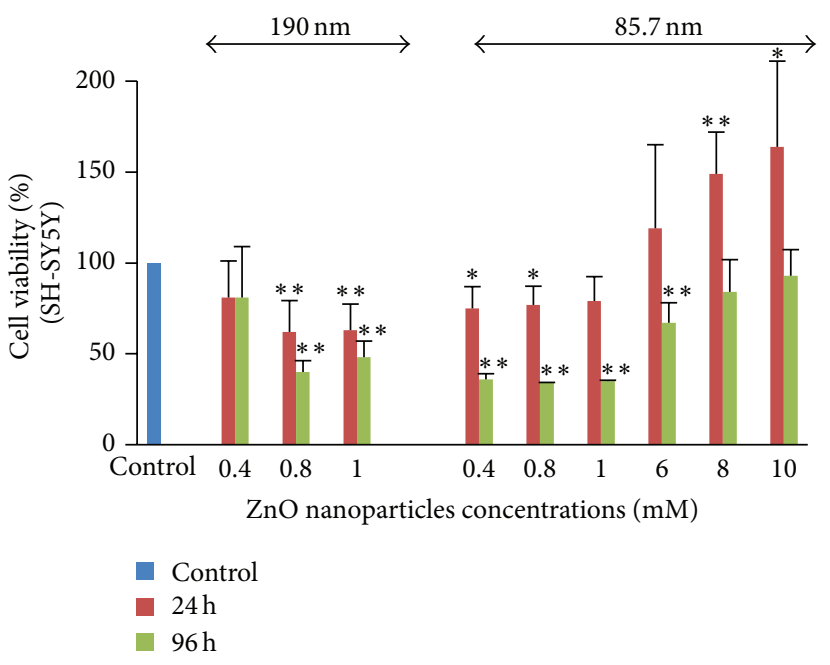

(a)

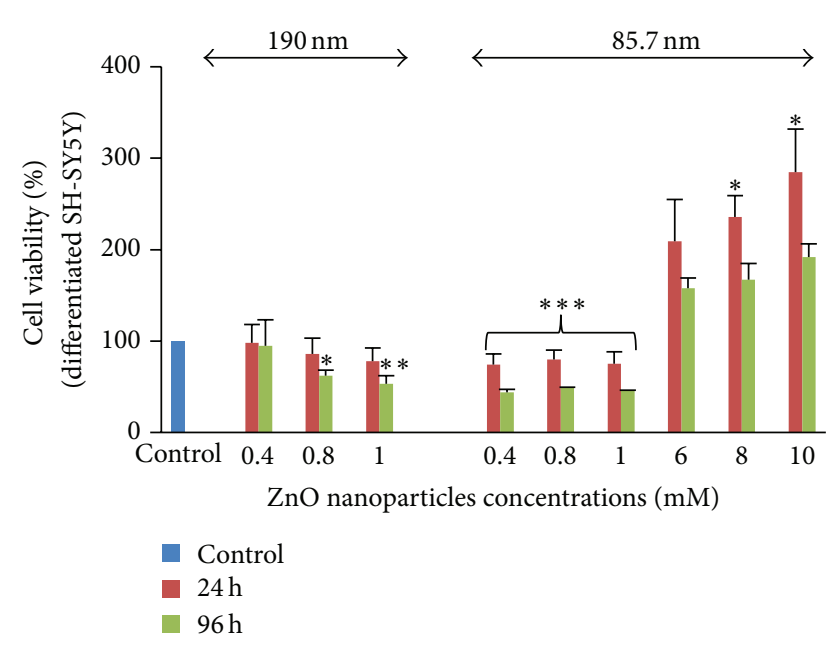

(b)

FIGURE 9: (a) Cytotoxicity effects of ZnO nanoparticles Z1 (85.7 nm) and Z2 (190 nm) in SH-SY5Y cells; (b) neurotoxicity effects of Z1 and Z2 on cell viability in differentiated SH-SY5Y cell lines after 24 or $96 \mathrm{~h}$ incubation. Control represents untreated cell lines. Values are means \pm $\mathrm{SD}(n=3)$ and all comparisons were made using two-tailed Student's $t$-test $\left({ }^{*} P<0.05 ;{ }^{* *} P<0.01 ;{ }^{* * *} P<0.001\right)$

$\mathrm{ZnO}$ nanoparticles. The lymphoma cell lines treated with $\mathrm{ZnO}$ nanoparticles were under the same conditions as described above for the other cell lines. U937 cell lines almost maintain $95-100 \%$ cell viability up to $1 \mathrm{mM}$ concentration after exposure to $\mathrm{ZnO}$ nanoparticles $\mathrm{Z} 1$ and $\mathrm{Z} 2$ for $24 \mathrm{~h}$ (Figure 10). While the longer incubation for $96 \mathrm{~h}$ significantly decreases the cell survival to $40-50 \%$ with either size of $\mathrm{ZnO}$ nanoparticles at concentrations ranging between 0.8 and $1 \mathrm{mM}$ ( $P$ 's $<0.01)$. Cytotoxicity of $\mathrm{ZnO}$ nanoparticles of either size did not show significant differences from each other in the U937 cell lines at concentrations ranging between 0.8 and $1 \mathrm{mM}$. From our literature review no studies were reported on nanoparticles cytotoxicity in lymphoma (U937) cell lines.
3.7. Particles Size and Duration of Exposure. It has been demonstrated that different particle size of the $\mathrm{ZnO}$ may have distinctly different physical properties and behave differently in cytotoxic studies. Our results show that smaller particles $(85.7 \mathrm{~nm})$ have more cytotoxic activity in cell lines tested (Hs888Lu, SH-SY5Y, and differentiated SH-SY5Y). While $\mathrm{ZnO}$ nanoparticles do not show toxicity in lung cancer (A549) and lymphoma (U937) cell lines after exposure to either size of $\mathrm{ZnO}$ nanoparticles. This is in agreement with the study demonstrated by Lin and coworkers (2009) stating that cell viability was not particle size dependent at all particle diameters (70 and $420 \mathrm{~nm}$ ) in A549 cell lines at $24 \mathrm{~h}$ incubation. The size dependent results of our work can be explained by the fact that for small particle size $\mathrm{ZnO}$, diffusion 


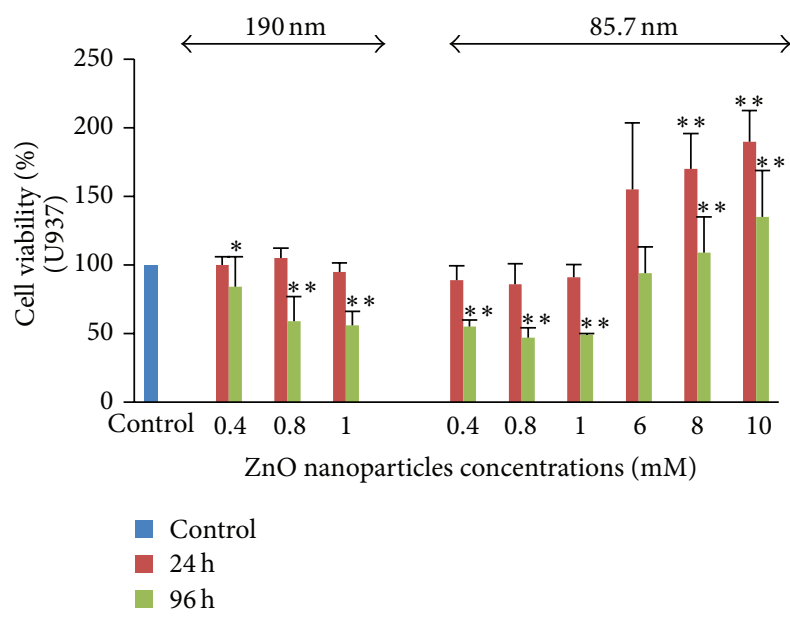

FIGURE 10: The response of lymphoma cells (U937) exposed to $\mathrm{ZnO}$ nanoparticles Z1 $(85.7 \mathrm{~nm})$ and Z2 $(190 \mathrm{~nm})$ for 24 or $96 \mathrm{~h}$. Control represents untreated cell lines. Values are means $\pm \operatorname{SD}(n=3)$ and all comparisons were made using two-tailed Student's $t$-test $\left({ }^{*} P<0.05\right.$; $\left.{ }^{* *} P<0.01 ;{ }^{* * *} P<0.001\right)$.

into the cells will be facilitated and thus the detrimental effect on them more pronounced.

The duration of exposure is one of the important parameters in any in vitro cytotoxicity assay. Thus, longer exposure periods may be necessary for screening the effects of metal oxide nanoparticles. The results in Figures $8-10$ prove that the longer the incubation time with $\mathrm{ZnO}$ nanoparticles is (either group) the more harmful the effect to the cell lines is. This is in agreement with previous studies that revealed a time dependent cytotoxicity of A549 [23], human epidermal (A431) [21], human mesothelioma MSTO-211H, and rodent 3T3 fibroblast cells [42] on exposure to $\mathrm{ZnO}$ nanoparticles. Similar cytotoxic effects were obtained in the glioma cell lines (LN18, LN229) and normal human astrocytes, treated with $10 \mathrm{mM} \mathrm{ZnO}$ nanoparticles for 24 and $72 \mathrm{~h}$ [41].

\section{Conclusion}

The data from the present study demonstrate that the presence of $\mathrm{ZnO}$ at high concentrations affected the cytotoxicity measurements due to the absorption characteristic of $\mathrm{ZnO}$ nanoparticles. The data revealed that the $\mathrm{ZnO}$ nanoparticles with an average particle size of around $85.7 \mathrm{~nm}$ and $190 \mathrm{~nm}$ induced cytotoxicity towards U937, SH-SY5Y, differentiated SH-SY5Y, and Hs888Lu cell lines. The ZnO nanoparticles were found inactive in lung cancer cell line (A549). Moreover, our data have also indicated that the cytotoxicity of $\mathrm{ZnO}$ was particle size, concentrations, and time dependent. Hence, the results of this study demonstrated that a $\mathrm{ZnO}$ nanoparticle at concentrations above $1 \mathrm{mM}$ has a profound influence on the cytotoxic effects of nanoparticles in different cell lines. Further studies will attempt to investigate the underlying mechanisms of this phenomenon.

\section{Conflict of Interests}

The authors declare that there is no conflict of interests regarding the publication of this paper.

\section{Acknowledgments}

This study is supported by FRGS fund $\{600-$ RMI/ST/FRGS 5/3/Fst (11/2008) $\}$ and the Institute of Science, University Technology MARA internal funds. A special thanks to Dr. Wong Tin Wui at Faculty of Pharmacy/UiTM for using confocal microscope.

\section{References}

[1] A. Kahru and H.-C. Dubourguier, "From ecotoxicology to nanoecotoxicology," Toxicology, vol. 269, no. 2-3, pp. 105-119, 2010.

[2] J. C. K. Lai, M. B. Lai, S. Jandhyam et al., "Exposure to titanium dioxide and other metallic oxide nanoparticles induces cytotoxicity on human neural cells and fibroblasts," International Journal of Nanomedicine, vol. 3, no. 4, pp. 533-545, 2008.

[3] M. Willander, Q. X. Zhao, Q.-H. Hu et al., "Fundamentals and properties of zinc oxide nanostructures: optical and sensing applications," Superlattices and Microstructures, vol. 43, no. 4, pp. 352-361, 2008.

[4] A. Nel, T. Xia, L. Mädler, and N. Li, “Toxic potential of materials at the nanolevel," Science, vol. 311, no. 5761, pp. 622-627, 2006.

[5] L. Reijnders, "Cleaner nanotechnology and hazard reduction of manufactured nanoparticles," Journal of Cleaner Production, vol. 14, no. 2, pp. 124-133, 2006.

[6] G. Ramakrishna and H. N. Ghosh, "Effect of particle size on the reactivity of quantum size $\mathrm{ZnO}$ nanoparticles and chargetransfer dynamics with adsorbed catechols," Langmuir, vol. 19, no. 7, pp. 3006-3012, 2003.

[7] S. Y. Bae, H. W. Seo, and J. Park, "Vertically aligned sulfur-doped $\mathrm{ZnO}$ nanowires synthesized via chemical vapor deposition," Journal of Physical Chemistry B, vol. 108, no. 17, pp. 5206-5210, 2004.

[8] E. Comini, G. Faglia, G. Sberveglieri, Z. Pan, and Z. L. Wang, "Stable and highly sensitive gas sensors based on semiconducting oxide nanobelts," Applied Physics Letters, vol. 81, no. 10, pp. 1869-1871, 2002.

[9] X. D. Bai, P. X. Gao, Z. L. Wang, and E. G. Wang, "Dual-mode mechanical resonance of individual $\mathrm{ZnO}$ nanobelts," Applied Physics Letters, vol. 82, no. 26, pp. 4806-4808, 2003.

[10] Y. Ding and Z. L. Wang, "Structure analysis of nanowires and nanobelts by transmission electron microscopy," Journal of Physical Chemistry B, vol. 108, no. 33, pp. 12280-12291, 2004.

[11] B. L. Zhu, C. S. Xie, D. W. Zeng, W. L. Song, and A. M. Wang, "Investigation of gas sensitivity of Sb-doped $\mathrm{ZnO}$ nanoparticles," Materials Chemistry and Physics, vol. 89, no. 1, pp. 148-153, 2005.

[12] Z. Huang, X. Zheng, D. Yan et al., "Toxicological effect of ZnO nanoparticles based on bacteria," Langmuir, vol. 24, no. 8, pp. 4140-4144, 2008.

[13] N. Serpone, D. Dondi, and A. Albini, "Inorganic and organic UV filters: their role and efficacy in sunscreens and suncare products," Inorganica Chimica Acta, vol. 360, no. 3, pp. 794-802, 2007. 
[14] A. Becheri, M. Dürr, P. Lo Nostro, and P. Baglioni, "Synthesis and characterization of zinc oxide nanoparticles: application to textiles as UV-absorbers," Journal of Nanoparticle Research, vol. 10, no. 4, pp. 679-689, 2008.

[15] M. Heinlaan, A. Ivask, I. Blinova, H.-C. Dubourguier, and A. Kahru, "Toxicity of nanosized and bulk $\mathrm{ZnO}, \mathrm{CuO}$ and $\mathrm{TiO}_{2}$ to bacteria Vibrio fischeri and crustaceans Daphnia magna and Thamnocephalus platyurus," Chemosphere, vol. 71, no. 7, pp. 1308-1316, 2008.

[16] N. M. Franklin, N. J. Rogers, S. C. Apte, G. E. Batley, G. E. Gadd, and P. S. Casey, "Comparative toxicity of nanoparticulate $\mathrm{ZnO}$, bulk $\mathrm{ZnO}$, and $\mathrm{ZnCl}_{2}$ to a freshwater microalga (Pseudokirchneriella subcapitata): the importance of particle solubility," Environmental Science and Technology, vol. 41, no. 24, pp. 8484-8490, 2007.

[17] V. Aruoja, H.-C. Dubourguier, K. Kasemets, and A. Kahru, "Toxicity of nanoparticles of $\mathrm{CuO}, \mathrm{ZnO}$ and $\mathrm{TiO}_{2}$ to microalgae Pseudokirchneriella subcapitata," Science of the Total Environment, vol. 407, no. 4, pp. 1461-1468, 2009.

[18] H. Wang, R. L. Wick, and B. Xing, "Toxicity of nanoparticulate and bulk $\mathrm{ZnO}, \mathrm{Al}_{2} \mathrm{O}_{3}$ and $\mathrm{TiO}_{2}$ to the nematode Caenorhabditis elegans," Environmental Pollution, vol. 157, no. 4, pp. 1171-1177, 2009.

[19] K. Kasemets, A. Ivask, H.-C. Dubourguier, and A. Kahru, "Toxicity of nanoparticles of $\mathrm{ZnO}, \mathrm{CuO}$ and $\mathrm{TiO}_{2}$ to yeast Saccharomyces cerevisiae," Toxicology in Vitro, vol. 23, no. 6, pp. 1116-1122, 2009.

[20] J. Chen, J. Zhu, H.-H. Cho et al., "Differential cytotoxicity of metal oxide nanoparticles," Journal of Experimental Nanoscience, vol. 3, no. 4, pp. 321-328, 2008.

[21] V. Sharma, R. K. Shukla, N. Saxena, D. Parmar, M. Das, and A. Dhawan, "DNA damaging potential of zinc oxide nanoparticles in human epidermal cells," Toxicology Letters, vol. 185, no. 3, pp. 211-218, 2009.

[22] I.-S. Kim, M. Baek, and S.-J. Choi, "Comparative cytotoxicity of $\mathrm{Al}_{2} \mathrm{O}_{3}, \mathrm{CeO}_{2}, \mathrm{TiO}_{2}$ and $\mathrm{ZnO}$ nanoparticles to human lung cells," Journal of Nanoscience and Nanotechnology, vol. 10, no. 5, pp. 3453-3458, 2010.

[23] W. Lin, Y. Xu, C.-C. Huang et al., "Toxicity of nano- and microsized $\mathrm{ZnO}$ particles in human lung epithelial cells," Journal of Nanoparticle Research, vol. 11, no. 1, pp. 25-39, 2009.

[24] K. Gerloff, C. Albrecht, A. W. Boots, I. Foerster, and R. P. F. Schins, "Cytotoxicity and oxidative DNA damage by nanoparticles in human intestinal Caco-2 cells," Nanotoxicology, vol. 3, pp. 355-364, 2009.

[25] C. Hanley, J. Layne, A. Punnoose et al., "Preferential killing of cancer cells and activated human $\mathrm{T}$ cells using $\mathrm{ZnO}$ nanoparticles," Nanotechnology, vol. 19, no. 29, Article ID 295103, pp. 1-10, 2008.

[26] J.-H. Yuan, Y. Chen, H.-X. Zha et al., "Determination, characterization and cytotoxicity on HELF cells of $\mathrm{ZnO}$ nanoparticles," Colloids and Surfaces B, vol. 76, no. 1, pp. 145-150, 2010.

[27] P. R. Lockman, J. M. Koziara, R. J. Mumper, and D. Allen, "Nanoparticle surface charges alter blood-brain barrier integrity and permeability," Journal of Drug Targeting, vol. 12, no. 9-10, pp. 635-641, 2004.

[28] S. B. Tiwari and M. M. Amiji, "A review of nanocarrier-based CNS delivery systems," Current Drug Delivery, vol. 3, no. 2, pp. 219-232, 2006.

[29] A. V. Zvyagin, X. Zhao, A. Gierden, W. Sanchez, J. A. Ross, and M. S. Roberts, "Imaging of zinc oxide nanoparticle penetration in human skin in vitro and in vivo," Journal of Biomedical Optics, vol. 13, no. 6, Article ID 064031, 2008.

[30] R. Rusdi, A. A. Rahman, N. S. Mohamed, N. Kamarudin, and N. Kamarulzaman, "Preparation and band gap energies of $\mathrm{ZnO}$ nanotubes, nanorods and spherical nanostructures," Powder Technology, vol. 210, no. 1, pp. 18-22, 2011.

[31] G. Malich, B. Markovic, and C. Winder, "The sensitivity and specificity of the MTS tetrazolium assay for detecting the in vitro cytotoxicity of 20 chemicals using human cell lines," Toxicology, vol. 124, no. 3, pp. 179-192, 1997.

[32] M. Encinas, M. Iglesias, Y. Liu et al., "Sequential treatment of SH-SY5Y cells with retinoic acid and brain-derived neurotrophic factor gives rise to fully differentiated, neurotrophic factor-dependent, human neuron-like cells," Journal of Neurochemistry, vol. 75, no. 3, pp. 991-1003, 2000.

[33] J. Singh and G. Kaur, "Transcriptional regulation of polysialylated neural cell adhesion molecule expression by NMDA receptor activation in retinoic acid-differentiated SH-SY5Y neuroblastoma cultures," Brain Research, vol. 1154, no. 1, pp. 821, 2007.

[34] A. Casey, E. Herzog, M. Davoren, F. M. Lyng, H. J. Byrne, and G. Chambers, "Spectroscopic analysis confirms the interactions between single walled carbon nanotubes and various dyes commonly used to assess cytotoxicity," Carbon, vol. 45, no. 7 , pp. 1425-1432, 2007

[35] R. H. Hurt, M. Monthioux, and A. Kane, "Toxicology of carbon nanomaterials: status, trends, and perspectives on the special issue," Carbon, vol. 44, no. 6, pp. 1028-1033, 2006.

[36] N. A. Monteiro-Riviere and A. O. Inman, "Challenges for assessing carbon nanomaterial toxicity to the skin," Carbon, vol. 44, no. 6, pp. 1070-1078, 2006.

[37] L. Belyanskaya, P. Manser, P. Spohn, A. Bruinink, and P. Wick, "The reliability and limits of the MTT reduction assay for carbon nanotubes-cell interaction," Carbon, vol. 45, no. 13, pp. 2643-2648, 2007.

[38] M. Davoren, E. Herzog, A. Casey et al., "In vitro toxicity evaluation of single walled carbon nanotubes on human A549 lung cells," Toxicology in Vitro, vol. 21, no. 3, pp. 438-448, 2007.

[39] S. H. Doak, S. M. Griffiths, B. Manshian et al., "Confounding experimental considerations in nanogenotoxicology," Mutagenesis, vol. 24, no. 4, pp. 285-293, 2009.

[40] J. M. Wörle-Knirsch, K. Pulskamp, and H. F. Krug, "Oops they did it again! Carbon nanotubes hoax scientists in viability assays," Nano Letters, vol. 6, no. 6, pp. 1261-1268, 2006.

[41] S. Ostrovsky, G. Kazimirsky, A. Gedanken, and C. Brodie, "Selective cytotoxic effect of $\mathrm{ZnO}$ nanoparticles on glioma cells," Nano Research, vol. 2, no. 11, pp. 882-890, 2009.

[42] T. J. Brunner, P. Wick, P. Manser et al., "In vitro cytotoxicity of oxide nanoparticles: comparison to asbestos, silica, and the effect of particle solubility," Environmental Science and Technology, vol. 40, no. 14, pp. 4374-4381, 2006. 

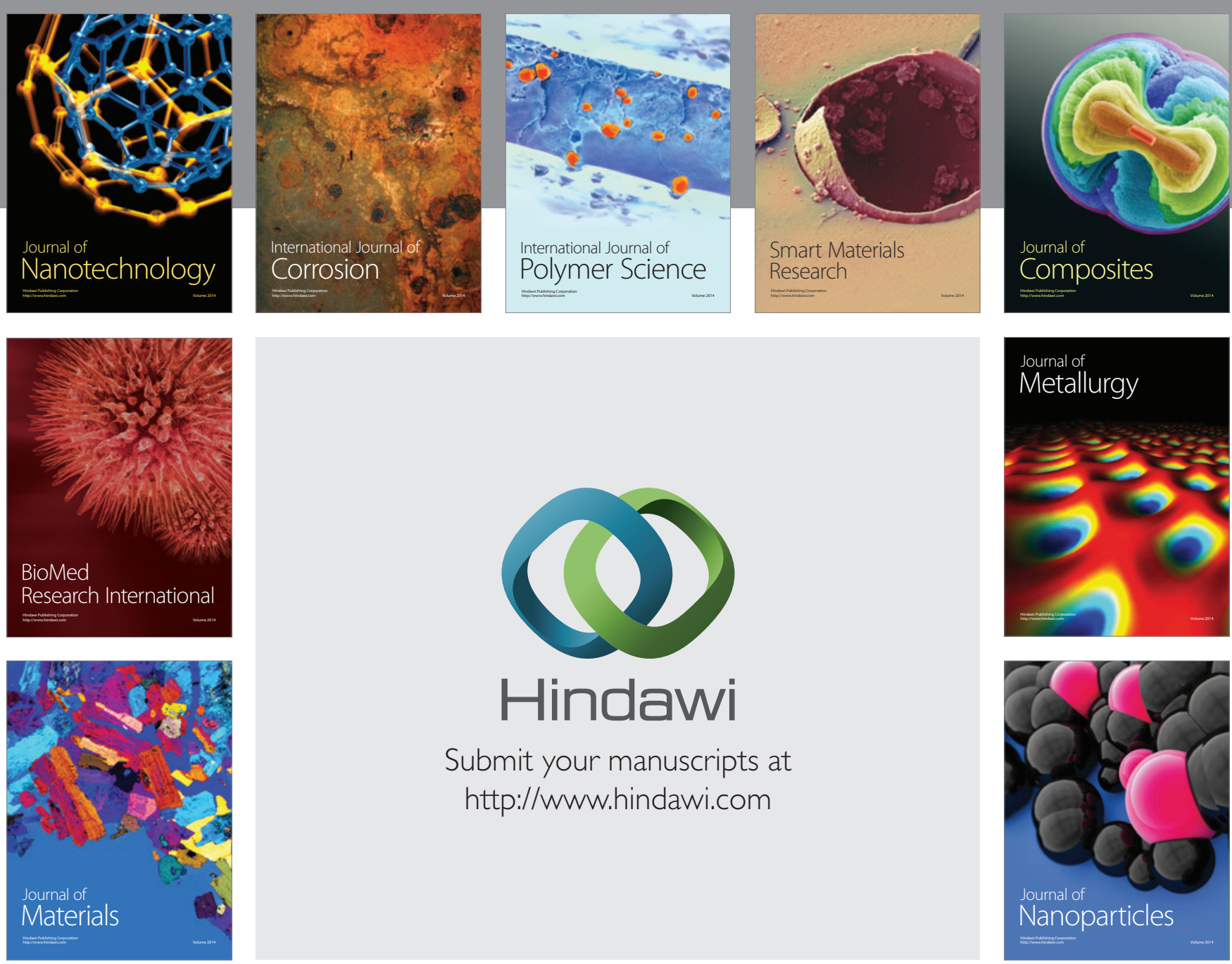

Submit your manuscripts at http://www.hindawi.com
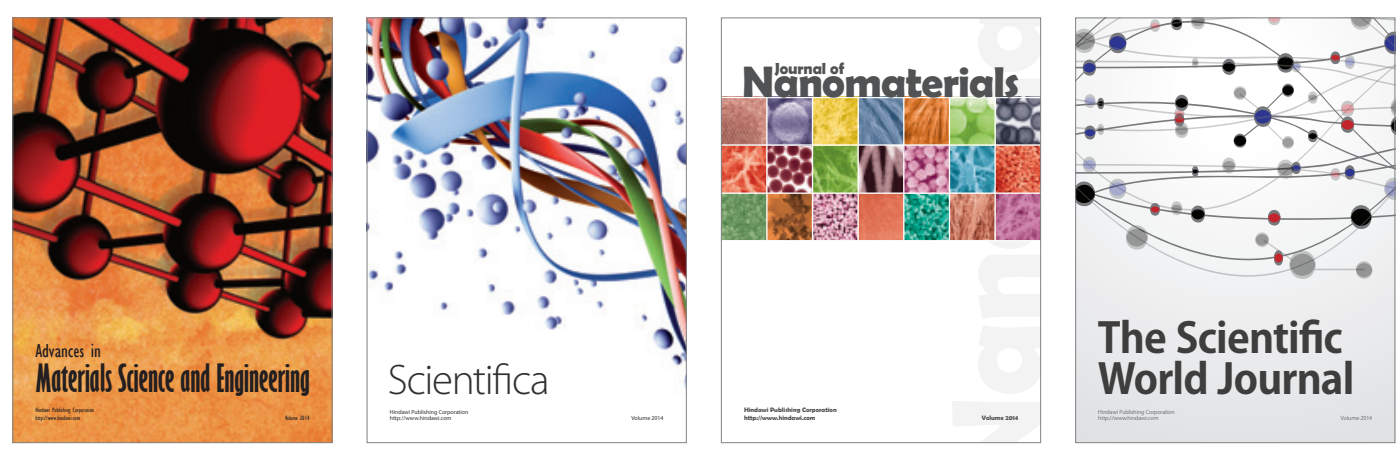

\section{The Scientific World Journal}
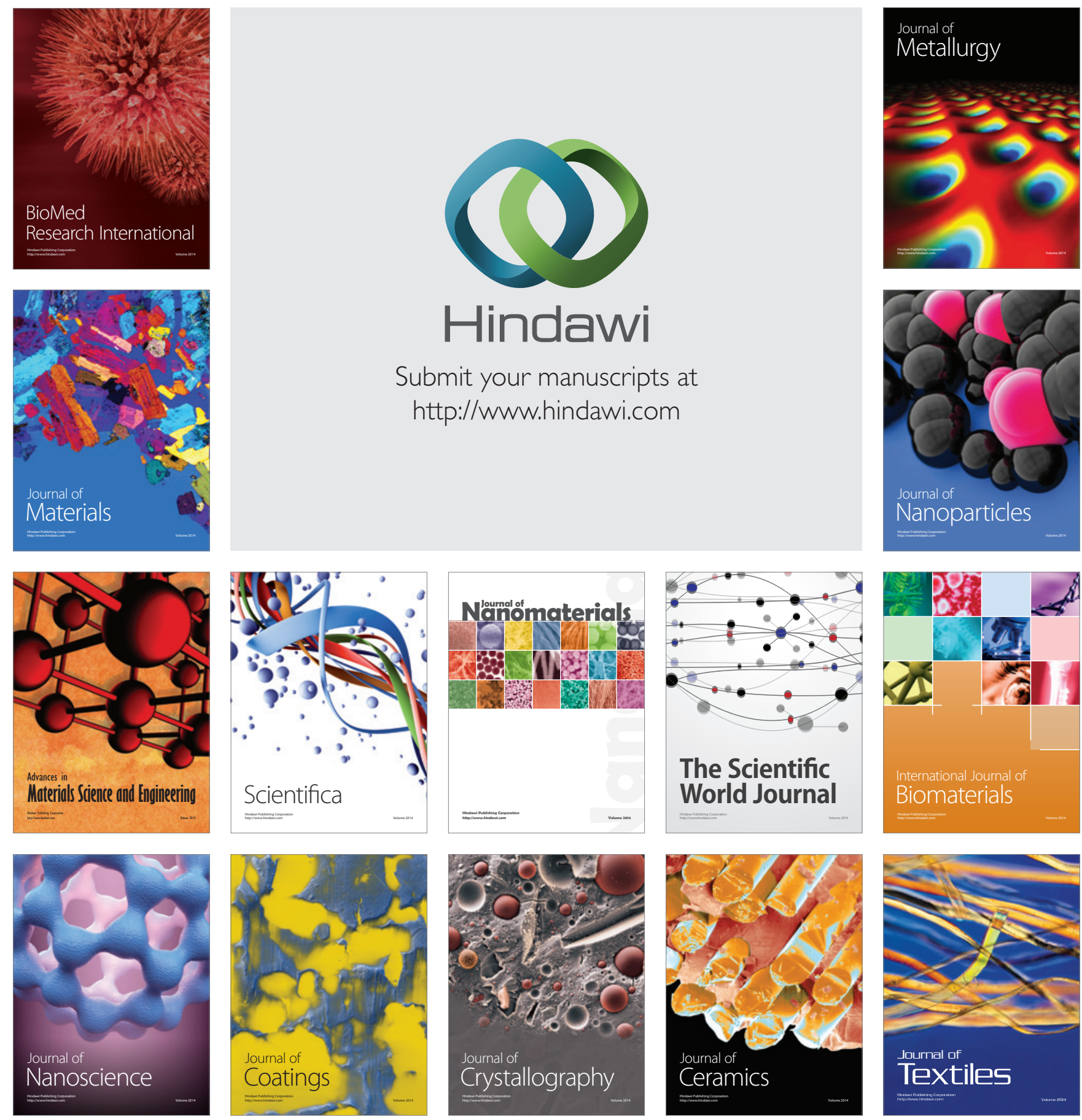